\section{Soil pH Affects Nutrient Balance in Cherry Rootstock Leaves}

\author{
H. Melakeberhan ${ }^{1,2}$, G.W. Bird ${ }^{2}$, and A.L. Jones ${ }^{3}$ \\ Michigan State University, East Lansing, MI 48824 \\ Additional index words. predisposition, Prunus avium, stone fruit decline
}

\begin{abstract}
This study was conducted as part of a stone fruit decline project to determine the effects of soil pH (3.9 to 7.0) on soil and plant nutrient imbalance and mortality of standard (Mazzard and Maheleb) and new (GI148-1 and GI148-8) rootstocks. Seedling mortality and soil $\mathrm{Ca}$ in all rootstocks and soil $\mathrm{K}$ and leaf $\mathrm{Ca}, \mathrm{K}, \mathrm{Al}$, and $\mathrm{Mn}$ contents in all rootstocks but GI148-8 were higher at below optimum than at optimum soil pH. The nutrient imbalance suggests that the adaptation of these rootstocks to biotic and abiotic factors needs to be considered.
\end{abstract}

The stone fruit decline syndrome in the United States has been attributed to biotic (Pseudomonas sp., nematodes, etc.) and abiotic (low soil $\mathrm{pH}$, nutrition, etc.) factors (see Melakeberhan et al., 1993 for reviews). In predominantly Mazzard (Prunus avium L.) rootstock-based Michigan cherry orchards, nematodes, bacterial canker, nutrition, winter injury, and low soil $\mathrm{pH}$ were associated with declining trees (Melakeberhan et al., 1993). Stratified rhizosphere analysis of soil in a declining sweet cherry orchard showed soil $\mathrm{pH}$ as low as 3.9 with increasing Al availability below $\mathrm{pH} 5.2$ and proportional absorption into plant tissue (Melakeberhan et al., 1995).

Significant resources are being devoted to developing better cherry rootstocks (Ferree and Perry, 1989). In addition to the standard rootstocks, Mazzard and Mahaleb, the Giesen lines are gaining attention because of their dwarfing characteristics. However, both the standard and the new rootstocks are suitable hosts for several plant-parasitic nematodes (Melakeberhan et al., 1994b). Furthermore, the effect of root-lesion nematode (Pratylenchus penetrans Cobb), the nematode most commonly associated with decline in Michigan cherry orchards, on these rootstocks was worse under nutrient-deficient than under nutrient-optimum conditions at a soil $\mathrm{pH}$ of 7.0 (Melakeberhan et al., 1997). Therefore, the objectives of this study were to determine the effects of below optimum soil $\mathrm{pH}$ on soil and plant nutritional imbalance and mortality of Mazzard, Mahaleb, GI148-1, and GI148-8 cherry rootstocks.

Received for publication 17 Apr. 2000. Accepted for publication 27 Nov. 2000. The technical assistance of J. Davenport and the financial support of the U.S. Dept. of Agriculture agreement \#88-341523380 and the Michigan Agricultural Experiment Station are greatly appreciated. The cost of publishing this paper was defrayed in part by the payment of page charges. Under postal regulations, this paper therefore must be hereby marked advertisement solely to indicate this fact.

${ }^{1}$ To whom reprint requests should be addressed. E-mail address: melakebe@msu.edu

${ }^{2}$ Dept. of Entomology.

${ }^{3}$ Dept. of Botany and Plant Pathology.

\section{Materials and Methods}

Two greenhouse experiments were conducted at $25 \pm 2{ }^{\circ} \mathrm{C}$. Expt. I consisted of 1 -yearold Mazzard seedlings planted in soil of $\mathrm{pH}$ 3.9, 4.7, and 7.0; Expt. II of Mazzard, Mahaleb, GI148-1, and GI148-8 seedlings in soil of $\mathrm{pH}$ 5.2 and 7.0. The $\mathrm{pH}$ of a steam-sterilized sandy loam ( $87 \%$ sand, $8 \%$ silt, $5 \%$ clay) soil was adjusted by mixing with $90 \%$ elemental sulfur powder at $0 \%$ to $0.7 \%$ by weight (Gupta and Cornfield, 1964) for $3 \mathrm{~min}$ in a cement mixer, and the soil was stored for 3 months in plastic barrels (Melakeberhan et al., 1995). Soil pH was checked every 2 weeks using a portable $\mathrm{pH}$ and soil moisture tester (O.S.K.E.M. System Soil Tester, Tokyo). Bare-root seedlings were obtained from Meadow Lake Nursery (McMinniville, Ore.) and stored at $4.5 \pm 1{ }^{\circ} \mathrm{C}$ for $\approx 50 \mathrm{~d}$ until budbreak. Before transplanting, seedlings were kept under laboratory conditions $\left(\approx 20 \pm 2{ }^{\circ} \mathrm{C}\right)$ with roots submerged in buckets containing tap water for $24 \mathrm{~h}$, selected for growth uniformity, and individually planted in $800 \mathrm{~mL}(944 \mathrm{~g})$ of soil in black plastic tubes $20 \mathrm{~cm}$ deep and $8 \mathrm{~cm}$ in diameter (Melakeberhan et al., 1994b, 1995). Seedlings were watered daily with tap water and fertilized twice weekly with $20 \mathrm{~N}-8.8 \mathrm{P}-16.6 \mathrm{~K}, 40$ mg N per application, (Peters 20-20-20 allpurpose fertilizer mix; Grace Sierra, Milpitas, Calif.). Four replications were used per treatment and the experiments were terminated 5 (Expt. I) and 15 weeks (Expt. II) after transplanting. Soil and plant nutrients were ana- lyzed as described in Melakeberhan et al. (1997). Data were analyzed using analysis of variance, and means separated by Tukey's HSD test.

\section{Results and Discussion}

In Expt. I, all seedlings planted in soil of $\mathrm{pH}$ 3.9 died within the fourth week of transplanting, indicating that the more unfavorable the soil conditions, the sooner seedlings died. A seedling was considered dead if all leaves or the entire shoot showed signs of wilt. Soil concentrations of $\mathrm{Ca}$ at $\mathrm{pH} 3.9\left(4.6 \mathrm{mg} \cdot \mathrm{g}^{-1}\right)$ and $4.7\left(4.2 \mathrm{mg} \cdot \mathrm{g}^{-1}\right)$ were significantly lower than at $\mathrm{pH} 7.0$ (6.4 $\mathrm{mg} \cdot \mathrm{g}^{-1}$ dry weight). The concentrations of $\mathrm{Al}$ in stems of trees growing in soil at $\mathrm{pH} 3.9\left(1433 \mu \mathrm{g} \cdot \mathrm{g}^{-1}\right)$ were higher $(P \leq 0.05)$ than those in soil at $\mathrm{pH} 4.7\left(235 \mu \mathrm{g} \cdot \mathrm{g}^{-1}\right)$ or 7.0 $\left(139 \mu \mathrm{g} \cdot \mathrm{g}^{-1}\right.$ dry weight $)$. The reduction of soil $\mathrm{Ca}$ and increase of $\mathrm{Al}$ in stems with decreasing $\mathrm{pH}$ indicates an increase in $\mathrm{Al}$ availability and proportional absorption by plant roots (Melakeberhan et al., 1995).

In Expt. II, concentrations of $\mathrm{Ca}$ and $\mathrm{K}$ in the soil were consistently less at $\mathrm{pH} 5.2$ than at pH 7.0 (Table 1). Concentrations of $\mathrm{K}$ and $\mathrm{Ca}$ in Mazzard, Mahaleb, and GI148-1 leaves were significantly less $(P \leq 0.05)$ in soil at $\mathrm{pH}$ 5.2 than at $\mathrm{pH} 7.0$, while the concentrations of $\mathrm{Al}$ and $\mathrm{Mn}$ were greater at $\mathrm{pH} 5.2$ than at $\mathrm{pH}$ 7.0 (Table 1). The lower level of $\mathrm{Ca}$ and $\mathrm{K}$ in leaves at $\mathrm{pH} 5.2$ (the average low pH commonly observed in declining orchards) than at $\mathrm{pH} 7.0$ is to be expected because the levels of these elements in soil can become deficient at low pH (Melakeberhan et al., 1993). The increase in $\mathrm{Mn}$ and $\mathrm{Al}$ are consistent with the effects of low $\mathrm{pH}$-driven nutrient imbalance (Melakeberhan et al., 1993; Neilsen et al., 1990). Despite significantly lower soil Ca levels at $\mathrm{pH} 5.2$ than at $\mathrm{pH} 7.0$ in GI148-8, there was no difference in leaf nutrient levels (Table 1). This may indicate possible physiological differences in nutrient uptake. Regardless of differences in leaf nutrient levels, however, all Mazzard and Mahaleb and 75\% of the GI148-1 and GI148-8 seedlings in soil with $\mathrm{pH} 5.2$ were dead within $10 \mathrm{~d}$ of the end of the study, thus clearly showing that the standard and new rootstocks are sensitive to low soil $\mathrm{pH}$.

Under orchard conditions, failure to lime regularly (Melakeberhan et al., 1993) and the use of $\mathrm{NH}_{4}^{+}$-based commercial fertilizers as

Table 1. The concentrations of $\mathrm{Ca}$ and $\mathrm{K}$ at pH 5.2 and 7.0 in soil, and the concentrations of $\mathrm{Ca}, \mathrm{K}, \mathrm{Mn}$, and $\mathrm{Al}$ in leaves of Mazzard, Mahaleb, GI148-1, and GI148-8 cherry rootstocks at 15 weeks after planting.

\begin{tabular}{|c|c|c|c|c|c|c|c|}
\hline \multirow[b]{3}{*}{ Rootstock } & \multirow[b]{3}{*}{ Soil pH } & \multicolumn{6}{|c|}{ Nutrient concn } \\
\hline & & \multicolumn{2}{|c|}{ Soil } & \multicolumn{4}{|c|}{ Leaves } \\
\hline & & $\mathrm{Ca}$ & $\mathrm{K}$ & $\mathrm{Ca}$ & $\mathrm{K}$ & $\mathrm{Mn}$ & $\mathrm{Al}$ \\
\hline & & \multicolumn{2}{|c|}{----- $\mathrm{mg} \cdot \mathrm{g}^{-1}$} & \multicolumn{2}{|c|}{$\mathrm{mg} \cdot \mathrm{g}^{-1}$} & \multicolumn{2}{|c|}{$\mu g \cdot g^{-1}$} \\
\hline \multirow[t]{2}{*}{ Mazzard } & 5.2 & $4.58 \mathrm{~b}^{\mathrm{z}}$ & $0.462 \mathrm{~b}$ & $06.9 \mathrm{~b}$ & $13.7 \mathrm{~b}$ & $377 \mathrm{a}$ & $131 \mathrm{a}$ \\
\hline & 7.0 & $5.72 \mathrm{a}$ & $0.808 \mathrm{a}$ & $10.7 \mathrm{a}$ & $17.6 \mathrm{a}$ & $76 \mathrm{~b}$ & $80 \mathrm{~b}$ \\
\hline \multirow[t]{2}{*}{ Mahaleb } & 5.2 & $5.34 \mathrm{~b}$ & $0.692 \mathrm{~b}$ & $10.8 \mathrm{~b}$ & $15.7 \mathrm{a}$ & $211 \mathrm{a}$ & $127 \mathrm{a}$ \\
\hline & 7.0 & $6.10 \mathrm{a}$ & $1.115 \mathrm{a}$ & $13.6 \mathrm{a}$ & $18.5 \mathrm{a}$ & $103 \mathrm{~b}$ & $78 \mathrm{~b}$ \\
\hline \multirow[t]{2}{*}{ GI 148-1 } & 5.2 & $3.46 \mathrm{~b}$ & $0.462 \mathrm{~b}$ & $09.0 \mathrm{~b}$ & $14.3 \mathrm{~b}$ & $143 \mathrm{a}$ & $208 \mathrm{a}$ \\
\hline & 7.0 & $5.84 \mathrm{a}$ & $0.962 \mathrm{a}$ & $13.8 \mathrm{a}$ & $17.5 \mathrm{a}$ & $116 \mathrm{a}$ & $51 \mathrm{~b}$ \\
\hline \multirow[t]{2}{*}{ GI $148-8$} & 5.2 & $2.18 \mathrm{~b}$ & $0.538 \mathrm{a}$ & $12.4 \mathrm{a}$ & $17.6 \mathrm{a}$ & $121 \mathrm{a}$ & $61 \mathrm{a}$ \\
\hline & 7.0 & $6.00 \mathrm{a}$ & $0.692 \mathrm{a}$ & $12.4 \mathrm{a}$ & $17.7 \mathrm{a}$ & $121 \mathrm{a}$ & $77 \mathrm{a}$ \\
\hline
\end{tabular}

${ }^{\mathrm{z}}$ Mean separation within rootstocks and elements by Tukey's HSD, $P \leq 0.05$. 
nitrogen sources (Peryea and Burrows, 1999) are among the reasons for low soil $\mathrm{pH}$. Neither the required time for a typical orchard soil $\mathrm{pH}$ to decline to the levels tested in the present study, nor how mature trees respond to the nutritional changes observed here, are known. This study shows that soil $\mathrm{pH}$ below the optimum range reduced soil and plant concentrations of $\mathrm{K}$ and $\mathrm{Ca}$ and increased $\mathrm{Al}$ and $\mathrm{Mn}$ concentrations in plant tissue. As $\mathrm{pH}$ declines below 5.5, the availability of $\mathrm{Al}$ and the potential for Al toxicity (Foy, 1974; Melakeberhan et al., 1995) and nutritional imbalance (Hoyt and Neilsen, 1985; Melakeberhan et al., 1993; Neilsen et al., 1990) increase, which, in turn, could lead to a predisposition to biotic factors and tree death (Melakeberhan et al., 1994a, 1997). Therefore, the adaptation of these rootstocks to soil abiotic and biotic factors needs to be considered carefully.

\section{Literature Cited}

Ferree, D.C. and R.L. Perry. 1989. NC 140 rootstock trials in North America. Acta Hort. 243:51-57.

Foy, C.D. 1974. Effects of aluminum on plant growth, p. 601-640. In: E.W. Carson (ed.). The plant root and its environment. Univ. Press of Virginia, Charlottesville.

Gupta, M.B.S. and A.H. Cornfield. 1964. Effect of four acidifying materials added to a calcareous soil on the availability of phosphorus to rye. Plant Soil 21:388-390.

Hoyt, P.B. and G.H. Neilsen. 1985. Effects of soil $\mathrm{pH}$ and associated cations on growth of apple trees planted in old orchard soil. Plant Soil 86:395-401

Melakeberhan, H., G.W. Bird, and R. Gore. 1997. Impact of Pratylenchus penetrans infection on Prunus avium rootstocks. J. Nematol. 29:381388.

Melakeberhan, H., G.W. Bird, and A.L. Jones. 1994a. Effect of soil $\mathrm{pH}$ on predisposing sweet cherry seedlings to pathogens. J. Nematol. 26:111. (Abstr.)

Melakeberhan, H., G.W. Bird, and R. Perry. 1994b. Plant-parasitic nematodes associated with cherry rootstocks in Michigan. J. Nematol. 26:967-772.

Melakeberhan, H., A.L. Jones, E. Hanson, and G.W. Bird. 1995. Effect of low soil pH on aluminum availability and on mortality of cherry seedlings. Plant Dis. 79:886-892.

Melakeberhan, H., A.L. Jones, P. Sobiczewski, and G.W. Bird. 1993. Factors associated with the decline of sweet cherry trees in Michigan: Nematodes, bacterial canker, nutrition, soil $\mathrm{pH}$, and winter injury. Plant Dis. 77:266-271.

Neilsen, G.H., D. Neilsen, and D. Atkinson. 1990. Top and root growth and nutrient absorption of Prunus avium $\mathrm{L}$. at two soil $\mathrm{pH}$ and $\mathrm{P}$ levels. Plant Soil 121:137-144.

Peryea, F.J. and R.L. Burrows. 1999. Soil acidification caused by four commercial nitrogen fertilizer solutions and subsequent soil $\mathrm{pH}$ rebound. Commun. Soil Sci. Plant Anal. 30:525-533. 